\title{
Une approche pluridisciplinaire de l'écologie montagnarde
}

\section{Martine Garrigues-Cresswell}

\section{(2) OpenEdition}

12 Journals

Édition électronique

URL : https://journals.openedition.org/tc/920

DOI : $10.4000 /$ tc. 920

ISSN : 1952-420X

Éditeur

Éditions de l'EHESS

\section{Édition imprimée}

Date de publication : 1 septembre 1986

ISSN : 0248-6016

\section{Référence électronique}

Martine Garrigues-Cresswell, « Une approche pluridisciplinaire de l'écologie montagnarde », Techniques \& Culture [En ligne], 7| 1986, mis en ligne le 23 janvier 2006, consulté le 29 septembre 2022. URL:

http://journals.openedition.org/tc/920 ; DOI : https://doi.org/10.4000/tc.920

Ce document a été généré automatiquement le 29 septembre 2022.

Tous droits réservés 


\section{Une approche pluridisciplinaire de l'écologie montagnarde}

Martine Garrigues-Cresswell 